\title{
Effects of Prosopis laevigata pods on growth performance, ruminal fermentation and blood metabolites in finishing lambs
}

\author{
L.Y. Peña-Avelino', J. M. Pinos-Rodríguez ${ }^{2 \#}$, B. I. Juárez-Flores ${ }^{3}$, \& L. Yáñez- \\ Estrada $^{4}$ \\ ${ }^{1}$ Facultad de Medicina Veterinaria y Zootecnia \\ Universidad Autónoma deTamaulipas, Cd. Victoria, México \\ ${ }^{2}$ Centro de Biociencias, ${ }^{3}$ Instituto de Investigación en Zonas Desérticas, ${ }^{4}$ Facultad de Medicina \\ Universidad Autónoma de San Luís Potosí, San Luis Potosí, 78000, S.L.P. México
}

(Received 20 August 2015; Accepted 17 August 2016; Published online 27 October 2016)

Copyright resides with the authors in terms of the Creative Commons Attribution 2.5 South African Licence.
See: http://creativecommons.org/licenses/by/2.5/za
Condition of use: The user may copy, distribute, transmit and adapt the work, but must recognise that authors and the South African
Journal of Animal Science

\begin{abstract}
Twenty-one non-castrated male Rambouillet lambs $(21 \pm 1.44 \mathrm{~kg}$ body weight) were used to evaluate the effects of increasing dietary levels of Prosopis laevigata pods (PLP) in a $72 \mathrm{~d}$ growth performance trial. Three dietary treatments defined as PLP0 (control, $0 \mathrm{~g} \mathrm{PLP} / \mathrm{kg} \mathrm{DM}$ ), PLP250 (250 g PLP/kg DM), and PLP500 (500 g PLP/kg DM) were evaluated. Animals fed PLP250 and PLP500 had higher daily weight gain $(P<0.05)$ and feed intake $(P<0.01)$ than lambs fed PLP0. Feed conversion was improved by PLP addition in the diets. Feeding cost decreased linearly as the level of PLP in the diet increased. Blood urea- $N$ concentration increased linearly as PLP increased in the diet. Lambs fed PLP500 had higher $(P<0.05)$ blood uric acid concentrations than lambs fed PLP0 and PLP250. Ruminal total volatile fatty acid (VFA) increased linearly with increasing dietary PLP. Lambs fed PLP250 and PLP500 had higher ruminal ammonia N concentrations $(P<0.05)$ than lambs fed PLP0. Dietary inclusion of PLP did not affect health status of lambs. Prosopis laevigata pods can be used safely in finishing lambs' diets at $500 \mathrm{~g} / \mathrm{kg}$.
\end{abstract}

Keywords: carcass, feed cost, performance

\#Corresponding author: jpinos@uaslp.mx

\section{Introduction}

The Chihuahuan Desert extends over the central and northern portion of the Mexican plateau and projects into the southern part of the USA. This desert has a dry climate with a mean annual precipitation of $2335 \mathrm{~mm}$, most of which occurs in the summer (June-October). Animals are taken out to graze and browse the poor range vegetation. Thus, farmers have adopted semi-intensive and intensive systems for growing and fattening lambs. The adopted systems are based on conventional feed ingredients such as soybean meal, barley, sorghum, wheat, and maize grain. Although these ingredients are known to be excellent sources of nutrients, their prices have increased significantly in recent years. In the Chihuahuan Desert, Prosopis laevigata trees are well adapted and one hectare of rangeland (without irrigation) can produce $3.7 \mathrm{t} /$ ha of pods (as feed) annually, whereas maize grain yield is $0.57 \mathrm{t} / \mathrm{ha}$ (Ruiz, 2011).

Our previous study (Peña-Avelino et al., 2014) indicated that Prosopis laevigata pods (PLP) contained on average (dry matter basis) $7.8 \%$ crude protein (CP), $2.1 \%$ fat, 33\% neutral detergent fiber (NDF) and $22 \%$ free sugars, making them highly palatable and digestible. To our knowledge, no growth performance trials have evaluated high inclusion of PLP $(50 \%)$ in finishing lambs. With a different species ( $P$. juliflora), pods replacing forages at $30 \%$ of total diet did not affect growth performance, but replacing grains or concentrate at the same level, daily gain and feed conversion was negatively affected as compared with the control (Mahgoub et al., 2004; 2005a,b; Obeidat et al., 2008). These inconclusive results may be due to the nutritional value of PLP, which is higher than forages but lower than grains (Peña-Avelino et al., 2014). Thus, when PLP replace conventional feedstuffs, diet reformulation would have to be considered. In cattle, detrimental effects on growth performance has been attributed to high 
proportions of $P$. juliflora pods $(>60 \%)$ in the diet (Cook et al., 2008). In $P$. juliflora, secondary components as alkaloids (Nakano et al., 2004), hemeaglutins (Becker 1982), trypsin inhibitor (Zolfaghari \& Harden, 1982) and tannins (Horton et al., 1993) have been identified and they may induce negative effects on animal health. In PLP, we found a tannin concentration of $40 \mathrm{mg} / \mathrm{kg}$ DM (Peña-Avelino et al., 2014), which is too low to induce negative effects on production parameters. We hypothesized that PLP can replace conventional feeds in regions where water is limited. Therefore, the objective of this study was to evaluate the effects of partially replacing conventional feed (i.e., maize grain) with PLP on growth performance, ruminal fermentation, and serum chemistry parameters in finishing lambs.

\section{Materials and methods}

The study was conducted on a commercial sheep farm, Cerro de San Pedro, San Luis Potosí, México. All procedures involving animals complied with the regulations established by the Animal Protection Law enacted by the State of San Luis Potosí, Mexico. Twenty-one non-castrated Rambouillet male lambs, 21 months old and $22.5 \pm 1.4 \mathrm{~kg}$ initial body weight (BW) were used and housed individually in shaded pens $(1.2 \mathrm{~m} \times 0.8 \mathrm{~m})$ equipped with feeders. They were randomly assigned to one of the three experimental treatments and subjected to a 12-d period of adaptation to the diets. During this period, they fed on alfalfa hay, gradually changing to one of the experimental diets and fed twice daily (08:00 and 14:30 h) during an 84-d period (12-d adaptation to diets and 72-d for growth performance trial). The lambs were slaughtered at the end of the growth performance study in legally certified-inspected facility in accordance with NOM-033-SAG/ZOO-2014. The experimental diets (Table 1) contained different proportions of PLP: PLP0 (control diet with $0 \mathrm{~g} \mathrm{PLP} / \mathrm{kg} \mathrm{DM}$ ), PLP250 (diet with $250 \mathrm{~g} \mathrm{PLP} / \mathrm{kg} \mathrm{DM}$ ), and PLP500 (diet with $500 \mathrm{~g} \mathrm{PLP} / \mathrm{kg} \mathrm{DM}$ ). Diets were formulated to meet the requirements for a growth rate of $300 \mathrm{~g} / \mathrm{d}$ for (NRC, 1985) and prepared every two weeks during the study.

Amounts of feed offered to animals were calculated according to previous intake and adjustments were made as needed so that refused feed did not exceed $10 \%$ fresh base of daily intake. Refusals were weighed before distribution of morning diets the following day to evaluate diet intake, and representative samples of feed were taken for laboratory analysis. When feeders were found empty, the amount of feed offered was scaled up by $10 \%$ on the following day. The animals were weighed at the beginning of the study and every $12 \mathrm{~d}$ before the morning feeding. Average daily gain was calculated by subtracting the initial BW from the BW on each $12^{\text {th }}$ day and then dividing it by twelve. In this way, we had six repeated measures within the experimental period. Total weight gain was determined by subtracting initial BW from final BW.

Pods were collected in Cerro de San Pedro, air-dried and chopped with a Bear Cat mill fitted with a 3-inch screen (Crary Industries, Inc. West Fargo, ND, USA) prior to addition to the diets. This ensured thorough mixing and prevented selection. The processing of diets was manual. Cost of experimental diets was calculated based on market prices of conventional feedstuffs and PLP during the trial.

Samples of diets and pods were dried at $55^{\circ} \mathrm{C}$ in a forced-air oven until constant weight and then ground to pass through a $1 \mathrm{~mm}$ screen (Wiley mill, model 4; Arthur Thomas Co. Philadelphia, PA, USA. Dry matter, crude protein, and ash content was determined following AOAC procedures (2006). Ether extract was measured with a Fat Extractor (Labconco Corp., Kansas City, MO, USA). Neutral detergent fiber (NDF) and acid detergent fiber (ADF) were assayed according to procedures described by Van Soest et al. (1991) with modifications for use in ANKOM 200 fiber analyzers (ANKOM Technology Corporation, Fairport, N.Y.) The NDF procedure included sodium sulfite and alpha amylase (heat stable). Ruminal fluid samples were collected after slaughter, and $\mathrm{pH}$ was recorded using a $\mathrm{pH}$ meter (Fisher Accumet, Pittsburgh, PA, USA). Samples were acidified, cooled $\left(4^{\circ} \mathrm{C}\right)$ for 30 min and centrifuged $(25,000$ $x \mathrm{~g} ; 4^{\circ} \mathrm{C}$ for $20 \mathrm{~min}$ ). Supernatant fluid samples were analyzed for volatile fatty acid (VFA) concentration (Erwin et al., 1961) in a gas chromatograph (6890N, Agilent Technologies Systems, USA). Ammonia N of ruminal fluid was determined at $630 \mathrm{~nm}$ with a UV-VIS spectrophotometer (HP 8453; Agilent Technologies) according to McCullough (1967).

To assess the effect of treatments on serum chemistry parameters, blood samples were collected from all lambs on days 1, 36 and 72 of the experimental period. Blood samples were collected just before the lambs were fed in the morning $(08: 00 \mathrm{~h})$. Approximately $6 \mathrm{ml}$ of blood was collected in BD vacutainer tubes. Blood samples were centrifuged $\left(3400 \mathrm{~g} \mathrm{x} 15 \mathrm{~min}\right.$ ) and serum was stored at $-20^{\circ} \mathrm{C}$ until analysis. Creatinine (Creatinine Jaffe') and uric acid (Mono SL Elitech) were measured using ELITech Clinical System kits (France) in a spectrophotometer (Benchmark Microplate Reader, Bio-Rad laboratories, USA) 
and urea-N (Liqui- UV Lincoln laboratory, USA) was measured using a spectrophotometer (Springlab 100, Spinreact, Mexico).

Data were analyzed under a completely random design using the MIXED procedure (SAS, 2002). Animals were considered the random component and treatment the fixed component in the model. Repeated measures were used to analyze average daily gain, feed intake and feed conversion (six 12- $d$ periods) and serum parameters (two 36-d periods). Compound symmetry was used as a covariance structure. A polynomial contrast was used to test the linear or quadratic effects of PLP dietary level on measurements. A probability of less than or equal to $0.05(\mathrm{P} \leq 0.05)$ was considered a significant difference.

\section{Results and discussion}

The chemical composition of PLP in this study is showed in Table 1. Authors have reported some variation in chemical composition of mesquite pods (de la Rosa et al., 2006) collected in a region with higher rainfall. Hence, some of the differences in the chemical composition may be due to climate or different soil conditions.

Table 1 Ingredients and chemical composition of experimental diets.

\begin{tabular}{lcccc}
\hline & \multicolumn{2}{c}{ Prosopis laevigata pods, $/ \mathrm{kg} \mathrm{DM}$} & \\
\cline { 2 - 4 } & 0 & 250 & 500 & SEM $^{1}$ \\
\hline Ingredient (g/kg DM) & & & & \\
Maize grain, ground & 642 & 486 & 333 \\
Soybean meal, 440 g/kg CP & 142 & 147 & 152 \\
$\quad$ Prosopis laevigata pods & 0 & 250 & 500 \\
$\quad$ Corn stover & 206 & 107 & 5 \\
$\quad$ Mineral vitamin premix & 10 & 10 & 10 & \\
Feed cost/ton (US\$) & 457 & 405 & 347 & \\
Chemical composition (g/kg DM) & & & & \\
Dry matter & 957 & 958 & 957 & 2.17 \\
Crude protein & 143 & 144 & 150 & 2.68 \\
Neutral detergent fiber & 225 & 222 & 230 & 4.68 \\
Acid detergent fiber & 128 & 132 & 139 & 2.06 \\
Fat & 31 & 34 & 37 & 0.04 \\
Ash & 46.4 & 47.4 & 48.8 & 1.42 \\
Metabolizable energy (Mcal/kg) & 2.9 & 3.0 & 3.0 & 0.24 \\
\hline
\end{tabular}

${ }^{1}$ SEM, Standard error of means

${ }^{2}$ Chemical composition: dry matter: $858 \mathrm{~g} / \mathrm{kg}$; crude protein: $77 \mathrm{~g} / \mathrm{kg} D M$; neutral detergent fiber: $352 \mathrm{~g} / \mathrm{kg}$ DM; acid detergent fiber: $272 \mathrm{~g} / \mathrm{kg}$ DM; fat: $15 \mathrm{~g} / \mathrm{kg}$ DM; ash: $43 \mathrm{~g} / \mathrm{kg}$ DM; metabolizable energy: 2.9 $\mathrm{Mcal} / \mathrm{kg}$

${ }^{3}$ Composition per kg: Se 10 mg; K 215 mg; Fe 50 mg; Co 20 mg; Zn 50 mg; Mn1600mg; Cu 300 mg; I 70 mg; Ca 220 mg; P 280 mg; S 30 mg; salt 845 mg; urea 102 mg; vitamin A 150 MUl/kg; vitamin D25 $\mathrm{MUl} / \mathrm{kg}$; vitamin E $150 \mathrm{Ul} / \mathrm{kg}$; lasalocid $1.3 \mathrm{~g} / \mathrm{kg}$.

${ }^{4}$ Calculated based on ingredients prices at the time of trial, the price dollar was $\$ 12.87 \mathrm{MXN}$.

${ }^{5}$ Calculated based on tabular value of NRC (1985).

Nutrient composition of the three diets was similar (Table 1). The price of PLP0 diet was $\$ 457$ USD/t fresh base, and the PLP500 diet was $\$ 347$ USD/t. When maize grain was partially replaced by PLP, feed cost/t decreased by $24 \%$ and $11 \%$ for PLP500 and PLP250, respectively (Table 1 ). Our results showed that the use of PLP is an alternative that can provide economic benefits to the farmer, as indicated by other authors around the world (Mahgoub et al., 2005a,b; Obeidat et al., 2008; Obeidat \& Shdaifat, 2013). Prosopis pods are advantageous, relative to conventional feeds such as maize grain, because PLP is well distributed and adapted to arid and semi-arid climates. They are cheaper than maize grain, the cost of feed decreased for lambs fed PLP500 and PLP250, relative to lambs fed PLP0. These results show that PLP is a good source of low cost feed. Studies on the use of mesquite pods (Mahgoub et al., 2004, 2005a; Obeidat et al., 2008) in ruminant feed found that it was effective in reducing the cost of the diet at levels of up to $200 \mathrm{~g} / \mathrm{kg}$ in goats and $300 \mathrm{~g} / \mathrm{kg}$ in lambs. 
Lambs fed PLP500 gained 21.3\% more weight compared with PLP0 and only $4.3 \%$ more than PLP250 (Table 2). Average daily weight gain in PLP500 was superior to PLP0. Dry matter intake with the PLP500 diet was higher than that with the PLP250 and PLP0 diets. Lambs fed PLP250 and PLP500 had better feed conversion values with respect to PLP0, which means that lambs fed PLP required less feed to gain weight than lambs fed diets with no PLP. These results provide new information because no positive effects on productive parameters by PLP had been reported for an inclusion rate of $500 \mathrm{~g} / \mathrm{kg} \mathrm{DM}$. Our results disagree with those of Mahgoub et al., (2004, 2005a), who found reduced growth rate in goats and sheep with $P$. juliflora pods at 300 and $450 \mathrm{~g} / \mathrm{kg} \mathrm{DM}$. The differences between the results of our study and those of previous studies could be due to the reformulation of our experimental diets, whose content of non-structural carbohydrates and the reduced particle size by dietary inclusion of PLP made them more palatable and increased digestibility and DMI. The high content of non-structural carbohydrates (sugars, starches, organic acids, and fructans) and pectin in PLP, providing readily available energy, can explain the increase in feed intake. In agreement with Fimbres-Durazo et al. (2013), sucrose makes PLP highly palatable and stimulates rumen function well as. In addition, feed consumption in lambs fed PL500 improved possibly because PLP partially replaced corn stover. Because PLP was finely ground, PLP500 had a smaller particle size and therefore, a higher passage rate than the control diet. Thus, for short particles less time is necessary for mastication during ruminating cycles and ruminal fermentation improves (Engelhardt et al., 2006; Clauss et al., 2011). Yang \& Beauchemin (2007) indicated that improvements in the rumen fermentative process commonly induce increments of microbial $\mathrm{N}$ synthesis. The serological examination indicated that lambs fed PLP500 had higher blood uric acid and urea-N urea than lambs fed PLPO (Table 3).

Table 2 Growth performance of finishing lambs fed diets containing different levels of Prosopis laevigata pods

\begin{tabular}{lcccc}
\hline & \multicolumn{3}{c}{ Prosopis laevigata pods, g/kg DM } & \\
\cline { 2 - 4 } & 0 & 250 & 500 & SEM $^{1}$ \\
\hline Initial body weight, $\mathrm{kg}$ & 23.3 & 21.6 & 22.8 & 3.12 \\
Final body weight, $\mathrm{kg}$ & 37.7 & 39.1 & 41.1 & 4.31 \\
Total weight gain, $\mathrm{kg}^{\mathrm{Q}}$ & $14.4^{\mathrm{b}}$ & $17.5^{\mathrm{a}}$ & $18.3^{\mathrm{a}}$ & 2.09 \\
Average daily weight gain, $\mathrm{kg}^{\mathrm{Q}}$ & $0.200^{\mathrm{b}}$ & $0.243^{\mathrm{a}}$ & $0.254^{\mathrm{a}}$ & 0.020 \\
${\text { Dry matter intake, } \mathrm{kg} / \mathrm{d}^{\mathrm{L}}}_{\text {Feed conversion }^{\mathrm{C}}}$ & $1.03^{\mathrm{C}}$ & $1.1^{\mathrm{b}}$ & $1.2^{\mathrm{a}}$ & 0.05 \\
\hline
\end{tabular}

${ }^{1}$ SEM, Standard error of means

${ }^{L}$ Linear effects of dietary level of prosopis pods $(P<0.05)$

${ }^{Q}$ Quadratic effects of dietary level of prosopis pods $(P<0.05)$

${ }^{\mathrm{a}-\mathrm{c}}$ Means within the rows with different superscripts are different at $P<0.05$.

Table 3 Blood metabolites and rumen traits in finishing lambs fed diets containing different levels of Prosopis laevigata pods

\begin{tabular}{|c|c|c|c|c|}
\hline & \multicolumn{3}{|c|}{ Prosopis laevigata pods, g/kg DM } & \multirow[b]{2}{*}{ SEM } \\
\hline & 0 & 250 & 500 & \\
\hline \multicolumn{5}{|l|}{ Blood metabolites (mg/dL) } \\
\hline Creatinine & 1.3 & 1.0 & 0.9 & 0.17 \\
\hline Urea-N ${ }^{\mathrm{L}}$ & $26.5^{\mathrm{C}}$ & $34.4^{\mathrm{b}}$ & $38.0^{\mathrm{a}}$ & 1.71 \\
\hline Uric acid $^{\mathrm{U}}$ & $1.3^{\mathrm{b}}$ & $1.3^{\mathrm{b}}$ & $2.6^{a}$ & 0.37 \\
\hline \multicolumn{5}{|l|}{ Rumen traits } \\
\hline $\mathrm{pH}$ & 6.4 & 6.3 & 6.5 & 0.27 \\
\hline Ammonia $\mathrm{N}, \mathrm{mg} / \mathrm{L}^{\mathrm{Q}}$ & $72.8^{\mathrm{b}}$ & $89.8^{\mathrm{a}}$ & $87.1^{\mathrm{a}}$ & 3.89 \\
\hline Total VFA's, mmol/L $\mathrm{L}^{\mathrm{L}}$ & $54.5^{\mathrm{C}}$ & $68.9^{\mathrm{b}}$ & $87.1^{\mathrm{a}}$ & 7.81 \\
\hline Acetate, $\mathrm{mol} / 100 \mathrm{~mol}$ & 40.0 & 38.8 & 40.6 & 2.34 \\
\hline Propionate, $\mathrm{mol} / 100 \mathrm{~mol}$ & 38.0 & 37.3 & 39.1 & 3.20 \\
\hline Butyrate, $\mathrm{mol} / 100 \mathrm{~mol}$ & 22.0 & 23.9 & 20.3 & 3.48 \\
\hline Acetate: Propionate ratio & 1.05 & 1.04 & 1.03 & 0.15 \\
\hline
\end{tabular}

1 SEM, Standard error of means,

$L$ Linear effects of dietary level of prosopis pods $(P<0.05)$

${ }^{Q}$ Quadratic effects of dietary level of prosopis pods $(P<0.05)$ 
${ }^{\mathrm{a}-\mathrm{c}}$ Means within the rows with different superscripts are different at $P<0.05$.

In addition, lambs fed PLP had higher ruminal NH3-N and total VFA than lambs no fed PLP. This result supports the previous affirmation that soluble carbohydrates and particle size of PLP helped to improve rumen fermentation and maximize the efficiency of microbial protein synthesis (Eschenlauer et al., 2002. Ruminal pH and molar proportion of acetate, propionate and butyrate were not affected by PLP.

\section{Conclusion}

Prosopis laevigata pods can be used as an alternative dietary ingredient to substitute maize grain and reduce feed cost in lamb diets. The inclusion of Prosopis laevigata pods at $500 \mathrm{~g} / \mathrm{kg} \mathrm{DM}$ in lamb fattening diets improved average daily gain, feed intake and feed conversion because this feedstuff provided a good source of soluble carbohydrates and particle size to improve rumen $\mathrm{N}$ metabolism. This non-conventional ingredient is potentially valuable and is a cheap alternative dietary ingredient for livestock feeds in arid and semi-arid areas where $P$. laevigata trees grow.

\section{References}

AOAC, 2006. Official Methods of Analysis. (18th ed.). Association of Official Analitycal Chemists, Inc., Washinton, D.C., USA.

Becker, R., 1982. The nutritive value of Prosopis pods. In: Parker, H.W. (Ed.), Mesquite Utilization. College of Agricultural Sciences, Texas Tech University, Lubbock, TX, USA.

Clauss, M., Lechner, I., Barboza, P., Collins, W., Tervoort, T. A., Südekum, K. H., Codron, D. \& Hummel, J., 2011. The effect of size and density on the mean retention time of particles in the reticulorumen of cattle (Bos primigenius f. taurus), muskoxen (Ovibos moschatus) and moose (Alces alces). Br. J. Nutr. 105, 634-644.

Cook, R.W., Scott C.B. \& Hartmann F.S., 2008. Short-term mesquite pod consumption by goats does not induce toxicity. Rangeland Ecol. Manag. 61, 566-570.

de la Rosa, A.P.B., Frias-Hernández, J.T. Olalde-Portugal V. \& González, J., 2006. Processing, nutritional evaluation, and utilization of whole mesquite flour (Prosopis laevigata). J. Food Sci. 71, S315-S320.

Engelhardt, W.V., Haarmeyer, P., Kaske, M. \& Lechner-Doll, M., 2006. Chewing activities and oesophageal motility during feed intake, rumination and eructation in camels. J. Comp. Physiol. B 176, 117-124.

Erwin, E., Marco G. \& Emery, E., 1961. Volatile fatty acid analyses of blood and rumen fluid by gas chromatography. J. Dairy Sci. 44, 1768-1771.

Eschenlauer, S.C.P., McKain, N., Walker, N.D., McEwan, N.R., Newbold, C.J. \& Wallace, R.J., 2002. Ammonia production by ruminal microorganisms and enumeration, isolation, and characterization of bacteria capable of growth on peptides and amino acids from the sheep rumen. App. Environ. Microbiol. 68, 4925-4931.

Fimbres-Durazo, H., Ramírez-Romero, R., Michel-Gallegos, J.C. \& Kawas, J.R., 2013. Molasses level in lamb high-energy diets on productive performance, blood chemistry, liver minerals and histopathology. Livest. Sci. 157, 113-124.

Horton, G.M.J., Chesworth, J.M., Srikandakumar, A., Gumaa, K. \& Wohlt, J.E., 1993. Nutritional value of Acacia tortilis and Prosopis cineraria pods for sheep. J. Anim. Sci. 71, 271 (abstract).

Mahgoub, O., Kadim, I.T., Al-Ajmi, D.S., Al-Sagry, N.M., Al- Abri, A.S. \& Richie, A.R., 2004. The effects of replacing Rhodes Grass (Chloris gayana) hay with Ghaf (Prosopis cineraria) pods on the performance of Omani native sheep. Trop. Anim. Health Prod. 36, 281-294.

Mahgoub, O., Kadimm I.T., Johnson, H.E., Srikandakumar, A., Al-Saqui, N.M., Al- Abri, A.S. \& Ritchie, A., 2005a. The use of a concentrate containing Meskit (Prosopis juliflora) pods and date palm byproducts to replace commercial concentrate in diets of Omani sheep. Anim. Feed Sci. Technol. 120, 33-41.

Mahgoub, O., Kadim, I.T., Forsberg, N.E., Al-Ajmi, D.S., Al-Sagry, M.N, Al- Abri, A.S. \& Annamalai, K., 2005b. Evaluation of Meskit (Prosopis juliflora) pods as a feed for goats. Anim. Feed Sci. Technol. 121, 319-327.

McCullough, H.,1967. The determination of ammonia in whole blood by a direct colorimetric method. Clin. Chem. Acta 17, 297-304. 
Nakano, H., Nakajima, E., Hiradate, S., Fujii, Y., Yamada, K., Shigemori, H., \& Hasegawa, K., 2004. Growth inhibitory alkaloids from mesquite (Prosopis juliflora (Sw.) DC.) leaves. Phytochem. 65, 587-591.

Norma Oficial Mexicana NOM-033-SAG/ZOO 2014. Diario Oficial de la Federación, 26 de agosto de 2015, México

NRC, 1985. Nutrient Requirements of Sheep ( $6^{\text {th }}$ ed.). National Academy Press. Washington, DC. USA.

Obeidat, B.S. \& Shdaifat, M.M., 2013. Partial substitution of barley grain with Prosopis juliflora pods in lactating Awassi ewes' diets: Effect on intake, digestibility, and nursing performance. Small Rum. Res. 111, 50-55.

Obeidat, B.S., Abdullahand, A.Y. \& Al-Lataifeh, F.A., 2008. The effect of partial replacement of barley grains by Prosopis juliflora pods on growth performance, nutrient intake, digestibility, and carcass characteristics of Awassi lambs fed finishing diets. Anim. Feed Sci. Technol. 146, 42-54.

Peña-Avelino, L.Y., Pinos-Rodríguez, J.M., Yañez-Estrada, L., Juárez-Flores, B.I., Mejia, R. \& AndradeZaldivar, H., 2014. Chemical composition and in vitro degradation of red and white mesquite (Prosopis laevigata) pods. S. Afr. J. Anim. Sci. 44, 298-306.

Ruiz, T.D.R., 2011. Uso potencial de la vaina de mezquite para la alimentación de animales domésticos del Altiplano Potosino. M.Sc. thesis (unpublished). Universidad Autónoma de San Luis Potosí. (in spanish)

SAS, Statistical Analysis System. 2002. SAS/STAT 9 User's Guide. Carry, NC, USA: SAS Institute Inc.

Van Soest, P.J., Roberson, J.B. \& Lewis, B.A., 1991. Methods for dietary fibre, neutral detergent fibre, and non-starch polysaccharides in relation to animal nutrition. J. Dairy Sci. 74, 3583-3597.

Yang, W.Z. \& Beauchemin, K.A., 2007. Altering physically effective fiber intake through forage proportion and particle length: Digestion and milk production. J. Dairy Sci. 90, 3410-3421.

Zolfaghari, R. \& Harden, M., 1982. Nutritional value of Mesquite beans (Prosopis glandulosa). In: Parker, H.W. (Ed.), Mesquite Utilization. College of Agricultural Sciences, Texas Tech University, Lubbock, TX, USA, 1982, pp. 1-9. 